\title{
PENDUGAAN UMUR SIMPAN SUSU BUBUK FULL CREAM YANG DIKEMAS DENGAN ALUMUNIUM FOIL (AL7) ATAU METALIZED PLASTIC (VM-PET12) \\ SHELF LIFE PREDICTION OF ALUMUNIUM FOIL (AL7)/ METALIZED PLASTIC (VM-PET12) PACKAGED FULL CREAM MILK POWDER
}

\author{
PD Aprida1a, M Suprayatmi², R Hutami²
}

\begin{abstract}
1Taman Pagelaran BB 1 No.11 RT 04 RW 10, Kecamatan Ciomas, Kabupaten Bogor, Kode pos 16610.
${ }^{2}$ Jurusan Teknologi Pangan Fakultas Ilmu Pangan Halal Universitas Djuanda Bogor, Jl. Tol Ciawi No. 1, Kotak Pos 35 Ciawi, Bogor 16720.

aKorespondensi: PD Aprida, E-mail: putriadiahaprida19@gmail.com
\end{abstract}

(Diterima oleh Dewan Redaksi: 07-08-2017)

(Dipublikasikan oleh Dewan Redaksi: 25-10-2017)

\begin{abstract}
Milk powder is a sensitive food to temperature change during storage. This research was conducted by estimating the shelf life of milk powder which packed by alumunium foil (AL7) and metalized plastic (VM-PET12). Shelf life estimation methods were done by observing the moisture content using the oven and controlling the organoleptic by Difference from Control Test (DCT) to both of packaging. The products were stored at three different temperature levels, there were 37,47 and $55^{\circ} \mathrm{C}$. Observation time of this research were the $-0,7$ th, 14 th, 21st, 28th, and 35th day. Determination of critical quality parameters on shelf life estimation were done by choosing sample parameter that has the closest $\mathrm{R}^{2}$ value to 1 ; which was DCT value of full cream milk powder which packed by alumunium foil (AL7). Arrhenius equation of order 1 was generated based on the calculation that Ln $\mathrm{k}=38.597-13632(1 / \mathrm{T})$. The shelf life of alumunium foil (AL7) packaged product based on water content parameter was 17.2 months, while based on DCT value parameter was 50.2 months. The shelf life of metalized plastic (VM-PET12) packaged product based on water content parameter was 12.0 months, while based on DCT value parameter was 33.8 months.
\end{abstract}

Keywords: milk powder, alumunium foil (AL7), metalized plastic (VM-PET12), arrhenius

\section{ABSTRAK}

Susu bubuk merupakan produk pangan yang sensitif terhadap perubahan suhu selama penyimpanan. Pada penelitian ini dilakukan pendugaan umur simpan susu bubuk menggunakan alumunium foil (AL7) dan metalized plastic (VM-PET12). Pendugaan umur simpan dilakukan dengan mengamati parameter kadar air menggunakan metode oven dan organoleptik menggunakan metode pembedaan dengan kontrol atau Difference from Control Test (DCT) pada masing - masing jenis kemasan. Produk disimpan pada tiga tingkatan suhu yang berbeda yaitu 37,47 dan $55^{\circ} \mathrm{C}$. Waktu pengamatan yaitu hari ke $-0,7,14,21,28$, hingga 35. Penentuan parameter mutu kritis pendugaan umur simpan dipilih berdasarkan nilai $\mathrm{R}^{2}$ mendekati 1 yaitu DCT susu bubuk yang dikemas menggunakan alumunium foil (AL7). Persamaan Arrhenius ordo 1 yang dihasilkan berdasarkan perhitungan yaitu Ln $\mathrm{k}=$ 38.597 - 13632 (1/T). Umur simpan yang dikemas menggunakan alumunium foil (AL7) berdasarkan parameter kadar air yaitu 17.2 bulan, sedangkan berdasarkan DCT yaitu 50.2 bulan. Umur simpan susu bubuk yang dikemas menggunakan metalized plastic (VM-PET12) berdasarkan kadar air yaitu 12.0 bulan, sedangkan berdasarkan DCT yaitu 33.8 bulan.

Kata kunci: susu bubuk, alumunium foil (AL7), metalized plastic (VM-PET12), arrhenius

Aprida PD, M Suprayatmi, R Hutami. 2017. Pendugaan Umur Simpan Susu Bubuk Full Cream yang Dikemas dengan Alumunium Foil (AL7) atau Metalized Plastic (VM-PET12). Jurnal Agroindustri Halal 3(2): 097 - 104. 


\section{PENDAHULUAN}

Susu bubuk didefinisikan sebagai produk susu yang diperoleh dengan cara mengurangi sebagian besar air melalui proses pengeringan susu segar dan atau susu rekombinasi, atau pencampuran kering (dry blend), dengan atau tanpa penambahan vitamin, mineral, unsur gizi lainnya, dan bahan tambahan pangan yang diizinkan (SNI 2970, 2015). Selama proses penanganan, pengolahan, penyimpanan, dan distribusi produk pangan, mutu pangan akan mengalami perubahan karena adanya interaksi dengan berbagai faktor. Faktor tersebut antara lain transfer oksigen dan uap air. Produk yang diteliti adalah susu bubuk full cream. Produk ini memiliki karakteristik cukup rentan terhadap kerusakan yang disebabkan oleh transfer oksigen dan juga uap air. Oleh sebab itu, diperlukan bahan pengemas yang memiliki daya lindung baik terhadap transfer oksigen dan uap air.

Bahan pengemas alumunium foil (AL7) umumnya dipilih sebagai bahan pengemas yang sesuai untuk produk tersebut. Akan tetapi jika diamati lebih jauh, saat ini sudah ada pengembangan bahan pengemas lain yang memiliki karakteristik perlindungan mirip dengan alumunium foil (AL7) yaitu bahan pengemas metalized plastic (VM-PET12). Bahan dasar yang digunakan adalah plastik kemudian dilapisi alumunium.

Penelitian ini memiliki tujuan umum yaitu mengetahui umur simpan susu bubuk full cream dengan metode ASLT (Accelerated Self Life Test) model Arrhenius. Adapun tujuan khususnya adalah mengetahui umur simpan susu bubuk full cream yang dikemas dengan alumunium foil (AL7) dan metalized plastic (VM-PET12) melalui uji mutu organoleptik dan kadar air, serta mengetahui efektifitas AL7 dan VM-PET12 untuk digunakan sebagai pengemas susu bubuk.

\section{MATERI DAN METODE}

Susu bubuk yang digunakan dalam penelitian kali ini adalah susu bubuk full cream. Susu jenis ini merupakan susu yang tidak dikurangi lemaknya. Syarat mutu susu bubuk untuk kriteria organoleptik, kadar air dan lemaknya menurut SNI 2970 tahun 2015 dapat dilihat pada Tabel 1 berikut :

Tabel 1. Syarat mutu susu bubuk menurut SNI 2970:2015

\begin{tabular}{lccc}
\hline \multirow{2}{*}{$\begin{array}{l}\text { Kriteria } \\
\text { Uji }\end{array}$} & \multicolumn{3}{c}{ Persyaratan Susu Bubuk } \\
\cline { 2 - 4 } $\begin{array}{l}\text { Keadaan } \\
\text { Rasa }\end{array}$ & Normal & $\begin{array}{c}\text { Kurang } \\
\text { Lemak }\end{array}$ & $\begin{array}{c}\text { Bebas } \\
\text { Lemak }\end{array}$ \\
$\begin{array}{l}\text { Bau } \\
\text { Warna }\end{array}$ & Normal & Normal & Normal \\
$\begin{array}{l}\text { Kadar air } \\
(\% \text { bormal }\end{array}$ & $<5$ & Normal & Normal \\
$\begin{array}{l}\text { Lemak } \\
(\% \text { b/b) }\end{array}$ & $26-42$ & $1.5-26$ & $<1.5$ \\
\hline
\end{tabular}

Dijelaskan oleh Sampurno (2006), secara fungsional material untuk kemasan fleksibel dibagi menjadi sebagai berikut :

1. Material untuk cetak / main substrate (BOPP, PET, Ony (Oriented Film Nylon), paper, cellophane, alufoil).

2. Material untuk penghalang / barrier (BOPP, PET, Ony (Oriented Film Nylon), alufoil, cellophane, CPP).

3. Material untuk melekatkan material material di atas (adhesive, PE, PP)

4. Material untuk heat seal (CPP, LLDPE, LDPE, EAA, EVA, HSL, PP).

Guna mendapatkan suatu material multilayer yang memenuhi fungsi di atas material dengan sifat-sifat yang berlainan harus digabungkan dengan cara laminasi. Material penyusun alumunium foil yang digunakan dalam penelitian ini adalah PET12 / PE15 / AL7 / PE15 / LLDPE25.

Dijelaskan juga oleh Sampurno (2006), kemasan fleksibel yang tepat guna adalah kemasan multilayer yang dibuat dari laminasi bahan - bahan dengan mempertimbangkan segi biaya. Adapun urutan biaya tertinggi hingga terendah 
untuk kemasan fleksibel adalah sebagai berikut pada Tabel 2 :

Tabel 2. Kategori material dari segi biaya dan fungsinya

\begin{tabular}{ccccc}
\hline Biaya & $\begin{array}{c}\text { Material } \\
\text { Cetak }\end{array}$ & Perekat & $\begin{array}{c}\text { Material } \\
\text { Barrier }\end{array}$ & $\begin{array}{c}\text { Material } \\
\text { Heat seal }\end{array}$ \\
\hline Mahal & $\begin{array}{c}\text { PET } \\
\text { Nylon }\end{array}$ & Adhesive & $\begin{array}{c}\text { Alufoil } \\
\text { Nylon }\end{array}$ & CPP Retort \\
Sedang & OPP & LDPE & VM PET & CPP \\
& & (extrusion) & VM CPP & LLDPE \\
Mahal & & & PET & LDPE \\
& & & OPP & $\begin{array}{c}\text { (Extrusion) } \\
\text { PP (extrusion) }\end{array}$ \\
& & & &
\end{tabular}

Selain menggunakan material berkategori mahal yakni alufoil, dalam penelitian kali ini juga digunakan material dengan kategori biaya sedang yakni metalized plastic berupa VMPET (Vacuum Metalized Polyetilene). Material penyusun metalized plastic yang digunakan dalam penelitian ini adalah PET12 / PE15 / VMPET12 / PE15 / LLDPE25. Lapisan penunjang material ini sama seperti yang digunakan pada kemasan alufoil. Hanya lapisan barriernya saja yang berbeda, yakni VMPET12. Lapisan barrier menjadi titik kritis dalam penentuan umur simpan produk yang dikemas.

Jika dilihat dari titik kritis kerusakan susu bubuk selama penyimpanan maka bahan pengemas yang sesuai adalah alumunium foil, namun tidak menutup kemungkinan metalized plastic juga bisa digunakan. VMPET12 / Vacuum Metalized Polyetilene $12 \mu$ merupakan jenis metalized plastic yang paling umum digunakan dalam kemasan fleksibel untuk produk makanan. Berikut ini kemampuan barrier dari kedua jenis material kemasan tersebut pada Tabel 3 :

Tabel 3. Sifat barrier AL7 dan VM-PET12

\begin{tabular}{lccc}
\hline \multirow{2}{*}{ Material } & \multicolumn{3}{c}{ Barrier } \\
\cline { 2 - 4 } & WVTR & $\mathrm{O}_{2}$ TR & Aroma \\
\hline AL 7 & $0-1$ & $0-1$ & 000 \\
VM PET12 & $2-4$ & 50 & 000
\end{tabular}

Sumber : Sampurno (2006)
Faktor - faktor yang menyebabkan terjadinya perubahan pada produk pangan menjadi dasar dalam menentukan titik kritis umur simpan.Titik kritis ditentukan berdasarkan faktor utama yang sangat sensitif serta dapat menimbulkan terjadinya perubahan (Herawati, 2008). Adapun kriteria kadaluarsa beberapa produk pangan dapat dilihat pada Tabel 4 berikut :

Tabel 4. Kriteria kadaluarsa beberapa produk pangan

\begin{tabular}{|c|c|c|}
\hline Produk & $\begin{array}{c}\text { Mekanisme } \\
\text { Penurunan Mutu }\end{array}$ & $\begin{array}{c}\text { Kriteria } \\
\text { Kadaluarsa }\end{array}$ \\
\hline $\begin{array}{l}\text { Susu } \\
\text { bubuk }\end{array}$ & $\begin{array}{c}\text { Penyerapan uap air } \\
\text { dan oksidasi }\end{array}$ & $\begin{array}{l}\text { Pencoklatan dan } \\
\text { laju konsumsi } \mathrm{O}_{2}\end{array}$ \\
\hline $\begin{array}{l}\text { Makanan } \\
\text { bayi }\end{array}$ & Penyerapan uap air & $\begin{array}{c}\text { Off flavor - } \\
\text { perubahan warna }\end{array}$ \\
\hline $\begin{array}{l}\text { Makanan } \\
\text { kering }\end{array}$ & Penyerapan uap air & $\begin{array}{c}\text { Off flavor- } \\
\text { perubahan warna }\end{array}$ \\
\hline $\begin{array}{l}\text { Keripik } \\
\text { kentang }\end{array}$ & $\begin{array}{c}\text { Penyerapan uap air } \\
\text { dan oksidasi }\end{array}$ & Laju konsumsi $\mathrm{O}_{2}$ \\
\hline $\begin{array}{l}\text { Tepung } \\
\text { gandum }\end{array}$ & $\begin{array}{c}\text { Peneyrapan uap air } \\
\text { dan oksidasi }\end{array}$ & Laju konsumsi $\mathrm{O}_{2}$ \\
\hline
\end{tabular}

Penentuan umur simpan produk dengan metode ASS atau sering disebut dengan ASLT dilakukan dengan menggunakan parameter kondisi lingkungan yang dapat mempercepat proses penurunan mutu (usable quality) produk pangan. Pada metode ini kondisi penyimpanan diatur diluar kondisi normal sehingga produk dapat lebih cepat rusak dan penentuan umur simpan dapat dilakukan (Syalfina, 2007).

Metode akselerasi ini dapat dilakukan dalam waktu singkat dengan akurasi yang baik. Penentuan umur simpan produk dengan metode akselerasi dapat dilakukan dengan dua pendekatan, yaitu 1) pendekatan kadar air kritis dengan teori difusi menggunakan perubahan kadar air dan aktivitas air sebagai kriteria kadaluarsa dengan pemodelan kurva isoterm sorpsi air, dan 2) pendekatan semi empiris dengan bantuan persamaan Arrhenius, yaitu 
dengan teori kinetika yang pada umumnya menggunakan ordo nol atau ordo satu untuk produk pangan (Herawati, 2008).

Pada penentuan umur simpan menggunakan aplikasi prinsip kinetika diperlukan beberapa informasi diantaranya identifikasi faktor kritis, batasan mutu dan batas mutu minimum yang diharapkan / dijanjikan, parameter kinetika penurunan mutu (Ea, Q10, dll), dan kondisi mutu awal (Hariyadi, 2012). Rumusan umum kinetika penurunan mutu yaitu: Untuk penurunan mutu ordo nol (n $=0$ ) waktu kadaluarsa dapat diduga dengan menggunakan persamaan 1 dan untuk penurunan mutu ordo satu $(n=1)$ dapat diduga dengan menggunakan persamaan 2 .

$$
\begin{aligned}
& t_{s}=\left(Q_{0}-Q_{s}\right) / k \\
& t_{s}=\left[\operatorname{Ln}\left(Q_{0}-Q_{s}\right)\right] / k
\end{aligned}
$$

$\mathrm{t}_{\mathrm{s}}=$ waktu umur simpan;

$\mathrm{Q}_{0}=$ kualitas awal;

$\mathrm{Q}_{\mathrm{s}}=$ mutu akhir (mutu produk saat harus ditarik dari pasaran / mutu kritis);

$k=$ konstanta laju penurunan mutu

Diagram alir penelitian dapat dilihat dalam Gambar 1 berikut :

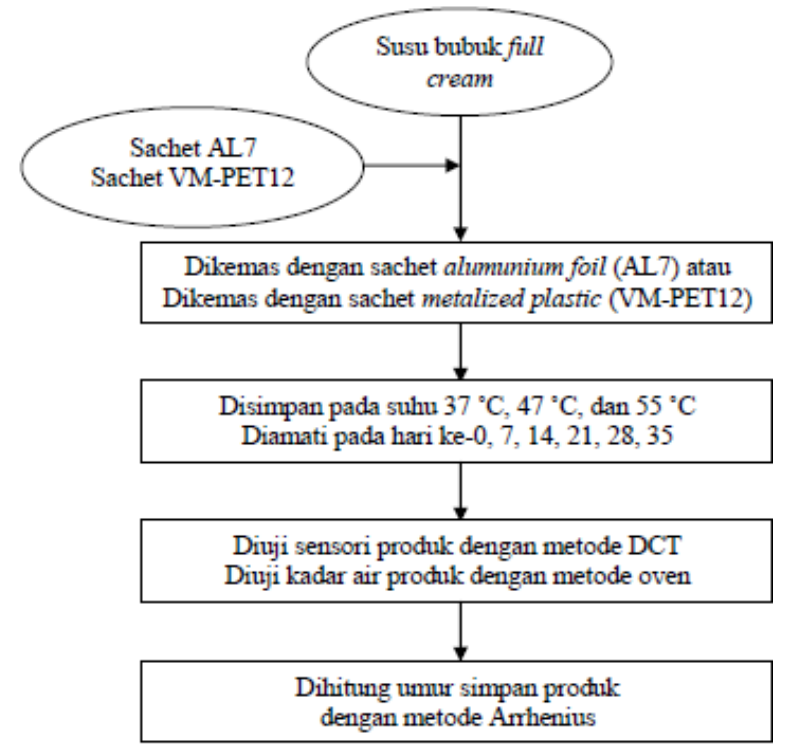

Gambar 1. Diagram alir penelitian

\section{HASIL DAN PEMBAHASAN}

\section{A. Kadar Air Susu Bubuk dengan Pengemas AL7}

Data hasil pengujian kadar air susu bubuk yang disimpan menggunakan kemasan AL7, perhitungan umur simpan mengikuti reaksi ordo 1 karena memiliki nilai $\mathrm{R}^{2}$ yang tinggi dibandingkan ordo 0 . $\mathrm{R}^{2}$ dari ordo 0 sebesar 0.9212 sedangkan $\mathrm{R}^{2}$ dari ordo 1 sebesar 0.9288. Maka umur simpan susu bubuk akan ditentukan berdasarkan reaksi ordo 1. Dengan melakukan perhitungan regresi linear antara lama penyimpanan dengan kadar air, didapat nilai $k$ atau konstanta laju penurunan mutu Arrhenius yang dapat dilihat pada Tabel 5 berikut :

Tabel 5. Nilai $k$ dan Ln $k$ kadar air pada

\begin{tabular}{|c|c|c|c|c|c|c|}
\hline $\begin{array}{c}\mathrm{T} \\
\left({ }^{\circ} \mathrm{C}\right)\end{array}$ & $\begin{array}{c}\mathrm{T} \\
(\mathrm{K})\end{array}$ & $1 / \mathrm{T}$ & $\operatorname{Ln} k_{\mathrm{t}}$ & $\begin{array}{c}\text { Slope } \\
(\mathrm{Ea} / \mathrm{R})\end{array}$ & $\begin{array}{c}\text { Intercept } \\
\left(\operatorname{Ln} k_{0}\right)\end{array}$ & $\mathrm{R}^{2}$ \\
\hline 37 & 310 & 0.0032 & -6.2 & \multirow[t]{3}{*}{-4770.448} & \multirow[t]{3}{*}{9.0305} & \multirow{3}{*}{ 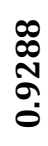 } \\
\hline 47 & 320 & 0.0031 & -6.0120 & & & \\
\hline 55 & 328 & 0.0030 & -5.4367 & & & \\
\hline
\end{tabular}
suhu penyimpanan AL7 ordo 1

Adapun grafik penurunan hubungan Ln $k_{\mathrm{t}}$ kadar air dengan 1/T AL7 ordo 1 dapat dilihat dalam Gambar 2 berikut :

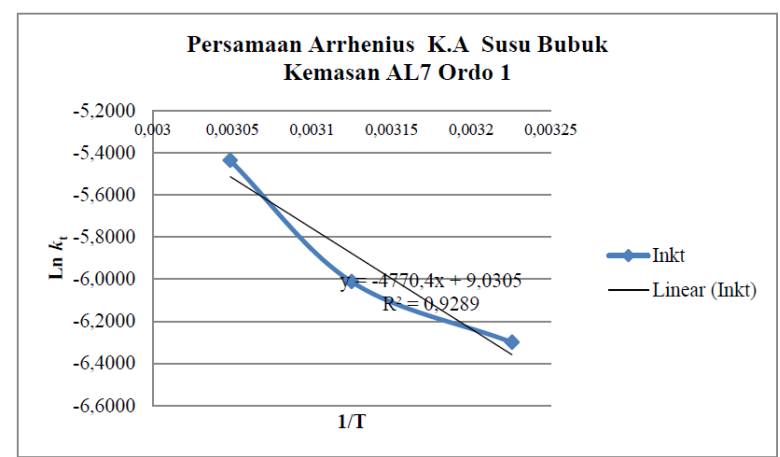

Gambar 2. Grafik Hubungan Ln $k_{\mathrm{t}} \mathrm{kadar}$ air dengan 1/T AL7 ordo 1

\section{B. Uji Organoleptik atau DCT (Difference from Control Test) Susu Bubuk dengan Pengemas AL7}

Selama penyimpanan berbagai suhu, nilai mutu sensori produk susu bubuk cenderung menurun hingga hari ke-35. Berikut gambar sampel susu bubuk yang dikemas menggunakan kemasan AL7 hari terakhir pengamatan / hari ke -35 pada berbagai suhu penyimpanan dapat dilihat pada Gambar 3 : 


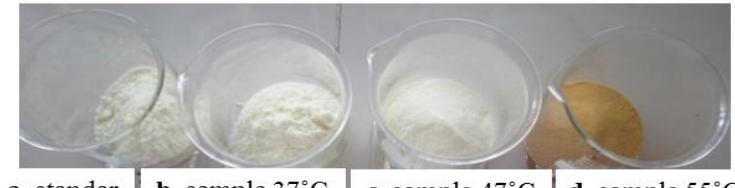

\begin{tabular}{l|l|l|l} 
a. standar & b. sample $37^{\circ} \mathrm{C}$ & c. sample $47^{\circ} \mathrm{C}$ & d. sample $55^{\circ} \mathrm{C}$
\end{tabular}

Gambar 3. Sampel susu bubuk yang dikemas AL7 hari ke-35

Gambar dari kiri ke kanan menunjukan standar susu bubuk yang disimpan dalam refrigerator, sampel susu bubuk dari inkubator $37{ }^{\circ} \mathrm{C}$, sampel susu bubuk dari inkubator suhu $47{ }^{\circ} \mathrm{C}$, dan sampel susu bubuk dari inkubator suhu $55^{\circ} \mathrm{C}$.

Perhitungan umur simpan susu bubuk dengan kemasan AL7 mengikuti reaksi ordo 1 karena memiliki nilai $\mathrm{R}^{2}$ tinggi mendekati 1 yaitu 0.9972 . Nilai $\mathrm{R}^{2}$ pada ordo 1 ini lebih tinggi jika dibandingkan dengan $\mathrm{R}^{2}$ dari ordo 0 yang hanya sebesar 0.9784 . Maka umur simpan susu bubuk ditentukan berdasarkan reaksi ordo 1. Dengan melakukan perhitungan regresi linear antara lama penyimpanan dengan kadar air, didapat nilai $k$ atau konstanta laju penurunan mutu Arrhenius yang dapat dilihat pada Tabel 6 berikut :

Tabel 6. Nilai $k$ dan Ln $k$ score DCT pada suhu penyimpanan AL7 ordo 1

\begin{tabular}{ccccccc}
\hline $\begin{array}{c}\mathrm{T} \\
\left({ }^{\circ} \mathrm{C}\right)\end{array}$ & $\begin{array}{c}\mathrm{T} \\
(\mathrm{K})\end{array}$ & $1 / \mathrm{T}$ & $\mathrm{Ln} k_{\mathrm{t}}$ & $\begin{array}{c}\text { Slope } \\
(\mathrm{Ea} / \mathrm{R})\end{array}$ & $\begin{array}{c}\text { Intercept } \\
\left(\mathrm{Ln} k_{\mathrm{o}}\right)\end{array}$ & $\mathrm{R}^{2}$ \\
\hline 37 & 310 & 0.0032 & -5.4086 & -13632.06 & 38.5972 & N \\
47 & 320 & 0.0031 & -3.9297 & & & $\sigma$ \\
55 & 328 & 0.0030 & -3.0055 & & & $\sigma$ \\
\hline
\end{tabular}

Adapun grafik penurunan hubungan Ln $k_{\mathrm{t}} \mathrm{DCT}$ dengan $1 / \mathrm{T}$ AL7 ordo 1 dapat dilihat dalam Gambar 4 berikut :

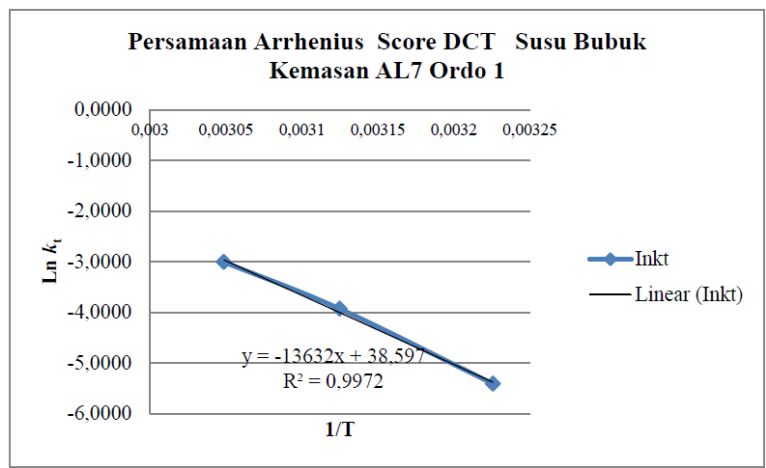

Gambar 4. Grafik hubungan Ln $k_{\mathrm{t}}$ score DCT dengan 1/T AL7 ordo 1

\section{Uji Kadar Air Susu Bubuk dengan Pengemas VM-PET12}

Data hasil pengujian kadar air susu bubuk yang disimpan menggunakan kemasan VM-PET12 menunjukan perhitungan umur simpan dapat mengikuti reaksi ordo 1 karena memiliki nilai $\mathrm{R}^{2}$ yang tinggi dibandingkan ordo 0 . Nilai $\mathrm{R}^{2}$ dari ordo 0 sebesar 0.5830, sedangkan nilai $\mathrm{R}^{2}$ dari ordo 1 sebesar 0.5839. Maka umur simpan susu bubuk akan ditentukan berdasarkan reaksi ordo 1. Dengan melakukan perhitungan regresi linear antara lama penyimpanan dengan kadar air, didapat nilai $k$ atau konstanta laju penurunan mutu Arrhenius yang dapat dilihat pada Tabel 7 berikut :

Tabel 7. Nilai $k$ dan Ln $k$ kadar air pada suhu penyimpanan VM-PET12 ordo 1

\begin{tabular}{|c|c|c|c|c|c|c|}
\hline $\begin{array}{c}\mathrm{T} \\
\left({ }^{\circ} \mathrm{C}\right) \\
\end{array}$ & $\begin{array}{c}\mathrm{T} \\
(\mathrm{K})\end{array}$ & $1 / \mathrm{T}$ & $\operatorname{Ln} k_{\mathrm{t}}$ & $\begin{array}{c}\text { Slope } \\
(\mathrm{Ea} / \mathrm{R})\end{array}$ & $\begin{array}{c}\text { Intercept } \\
\left(\operatorname{Ln} k_{\mathrm{o}}\right)\end{array}$ & $\mathrm{R}^{2}$ \\
\hline 37 & 310 & 0.0032 & -5.7866 & \multirow[t]{3}{*}{-4991.6} & \multirow[t]{3}{*}{10.1298} & \multirow{3}{*}{ 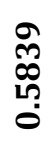 } \\
\hline 47 & 320 & 0.0031 & -5.8995 & & & \\
\hline 55 & 328 & 0.0030 & -4.8432 & & & \\
\hline
\end{tabular}

Adapun grafik penurunan hubungan Ln $k_{\mathrm{t}}$ kadar air dengan 1/T VM-PET12 ordo 1 dapat dilihat dalam Gambar 5 berikut :

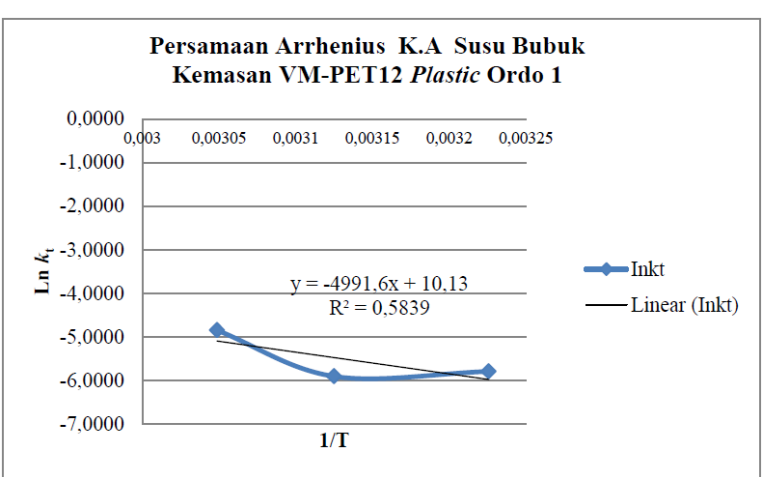

Gambar 5. Grafik Hubungan Ln $k_{\mathrm{t}} \mathrm{kadar}$ air dengan 1/T VM-PET12 ordo 1

\section{Uji Organoleptik atau DCT (Difference from Control Test) Susu Bubuk dengan Pengemas VM-PET12}

Semakin lama penyimpanan, maka semakin jauh nilai sampel uji terhadap kontrol. Berikut gambar sampel susu bubuk yang dikemas menggunakan 
kemasan VM-PET12 pada hari terakhir pengamatan / hari ke -35 pada berbagai suhu penyimpanan dapat dilihat pada Gambar 6 berikut :

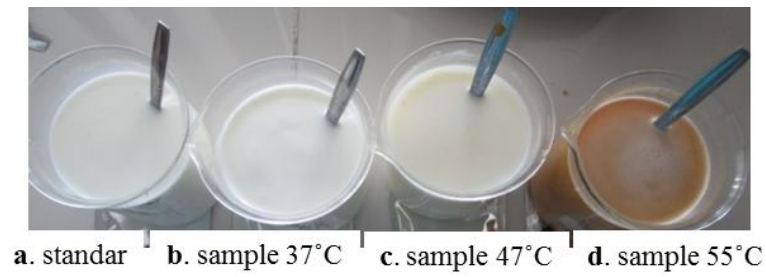

Gambar 6. Sampel susu bubuk yang dikemas VM-PET12 hari ke-35

Gambar dari kiri ke kanan menunjukan standar susu bubuk yang disimpan dalam refrigerator, sampel susu bubuk dari inkubator $37{ }^{\circ} \mathrm{C}$, sampel susu bubuk dari inkubator suhu $47{ }^{\circ} \mathrm{C}$, dan sampel susu bubuk dari inkubator suhu $55^{\circ} \mathrm{C}$.

Data hasil pengujian DCT susu bubuk yang dikemas menggunakan kemasan VM-PET12 menunjukan perhitungan umur simpan mengikuti reaksi ordo 1 karena memiliki nilai $\mathrm{R}^{2}$ lebih mendekati angka 1 dibandingkan dengan ordo 0 . Nilai $\mathrm{R}^{2}$ dari ordo 0 sebesar 0.9185 , sedangkan $\mathrm{R}^{2}$ dari ordo 1 sebesar 0.9686. Dengan melakukan perhitungan regresi linear antara lama penyimpanan dengan kadar air, didapat nilai $k$ atau konstanta laju penurunan mutu Arrhenius yang dapat dilihat pada Tabel 8 berikut :

Tabel 8. Nilai $k$ dan Ln $k$ score DCT pada suhu penyimpanan VM-PET12 ordo 1

\begin{tabular}{|c|c|c|c|c|c|c|}
\hline $\begin{array}{c}\mathrm{T} \\
\left({ }^{\circ} \mathrm{C}\right) \\
\end{array}$ & $\begin{array}{c}\mathrm{T} \\
(\mathrm{K})\end{array}$ & $1 / \mathrm{T}$ & $\operatorname{Ln} k_{\mathrm{t}}$ & $\begin{array}{l}\text { Slope } \\
\text { (Ea/R) }\end{array}$ & $\begin{array}{l}\text { Intercept } \\
\left(\operatorname{Ln} k_{\mathrm{o}}\right)\end{array}$ & $\mathrm{R}^{2}$ \\
\hline 37 & 310 & 0.0032 & -5.2043 & -12488.1 & 35.179 & ○ \\
\hline 47 & 320 & 0.0031 & -3.6165 & & & \\
\hline 55 & 328 & 0.0030 & -3.0255 & & & \\
\hline
\end{tabular}

Adapun grafik penurunan hubungan Ln $k_{\mathrm{t}} \mathrm{DCT}$ dengan $1 / \mathrm{T}$ VM-PET12 ordo 1 dapat dilihat dalam Gambar 7 berikut:

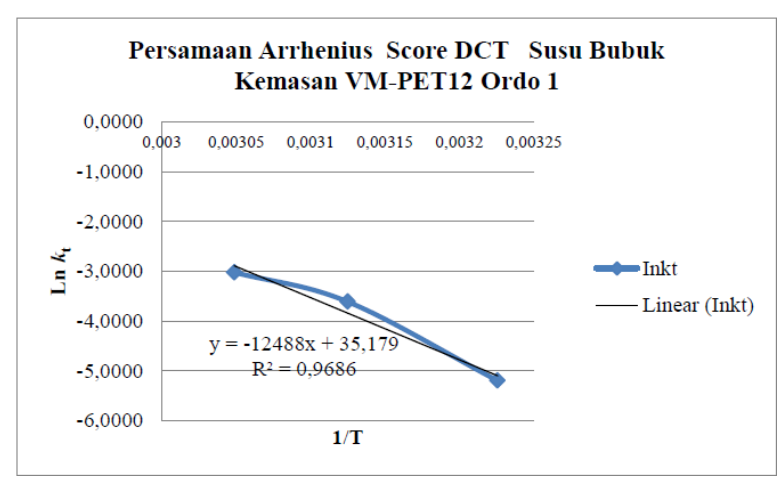

Gambar 7. Grafik hubungan Ln $k_{\mathrm{t}}$ score DCT dengan 1/T VM-PET12 ordo 1

\section{E. Perbandingan Umur Simpan Susu Bubuk Kemasan AL7 dan VM-PET12}

Tabel 9. Rekapitulasi nilai $\mathrm{R}^{2}$ dan parameter pendugaan umur simpan

\begin{tabular}{lllc}
\hline Pengemas & Parameter & Nilai R $^{2}$ & $\begin{array}{c}\text { Ordo reaksi } \\
\text { terpilih }\end{array}$ \\
\hline AL7 & Kadar air & 0.9288 & 1 \\
& DCT & 0.9972 & 1 \\
VM-PET12 & Kadar air & 0.5839 & 1 \\
& DCT & 0.9185 & 1 \\
\hline
\end{tabular}

Adapun perbandingan umur simpan susu bubuk yang dikemas dalam kemasan AL7 dan VM-PET12 dapat dilihat dalam Tabel 10 berikut :

\begin{tabular}{|c|c|c|c|c|c|}
\hline \multirow{2}{*}{$\begin{array}{c}\mathrm{T} \\
\text { Distri- } \\
\text { busi }\end{array}$} & \multirow{2}{*}{$\begin{array}{c}\text { Umur } \\
\text { simpan } \\
\text { dalam }\end{array}$} & \multicolumn{2}{|c|}{ AL7 } & \multicolumn{2}{|c|}{ VM-PET12 } \\
\hline & & $\begin{array}{c}\text { Kadar } \\
\text { air }\end{array}$ & DCT & $\begin{array}{c}\text { Kadar } \\
\text { air }\end{array}$ & DCT \\
\hline \multirow{3}{*}{$27 \circ C$} & Hari & 518.3 & 1508.5 & 360.8 & 1015.9 \\
\hline & Bulan & 17.2 & 50.2 & 12.0 & 33.8 \\
\hline & Tahun & 1.4 & 4.1 & 1.0 & 2.8 \\
\hline
\end{tabular}

Dapat dilihat pada Tabel 10 model kinetika reaksi yang cocok dengan nilai $\mathrm{R}^{2}$ tertinggi cenderung mendekati 1 yaitu parameter mutu organoleptik menggunakan metode DCT susu bubuk dengan orde reaksi 1 . Maka parameter mutu kritis pendugaan umur simpan susu bubuk dapat ditentukan berdasarkan parameter mutu organoleptik susu bubuk.

Perbedaan ketahanan kemasan tersebut disebabkan oleh adanya perbedaan material kemasan yang digunakan. Perbedaan terletak dari bahan barrier penyusun kedua jenis kemasan tersebut.Dijelaskan oleh Eskin dan 
Robinson (2001), transfer uap air yang terjadimelalui material polimer kemasan dilakukan dengan dua mekanisme yaitu difusi kapiler dan difusi aktif. Pada difusi kapiler, transfer uap air dilakukan melalui pori-pori kemasan atau pori-pori mikroskopik yang berbentuk kristal dan amorphous yang menyebabkan terjadinya difusi gas. Sedangkan difusi aktif adalah proses solubilitas dan difusi dimana uap air terlarut atau melebur pada permukaan polimer, lalu dengan adanya perbedaan tekanan maka terjadi difusi melalui polimer, selanjutnya uap air akan mengalir dan mengalami evaporasi ke sisi yang berlawanan.

Menurut Syarief, Santausa, dan Isyana (1989), kemasan alumunium foil tersusun dari bahan logam yang hermetis, fleksibel, dan tidak tembus cahaya sehingga memiliki sifat proteksi yang tinggi terhadap uap air, cahaya, lemak dan gas. Sementara itu bahan penyusun dari kemasan metalized plastic adalah PET (Polyethylene terephtalat). PET merupakan keluarga polyester. Polymer PET dapat diberi penguat fiber glass, atau filler mineral. PET film bersifat jernih, kuat, liat, dimensinya stabil, tahan nyala api, tidak beracun, permeabilitas terhadap gas, aroma, maupun air rendah. Untuk meningkatkan fungsinya, PET film dilapisi bahan metal yaitu metalized dimana kemasan metalized dapat dibuat secara vakum yaitu dengan pembentukan lembaran tipis.

Maka dari itu umur simpan susu bubuk relatif lebih panjang jika dikemas menggunakan alumunium foil karena menggunakan logam murni dengan beberapa tambahan aditif kemasan dalam proses pembuatannya dibandingkan metalized plastic. Namun tidak menutup kemungkinan metalized plastic juga dapat digunakan karena memiliki struktur dan sifat barrier yang hampir sama dengan alumunium foil.

Pemilihan kemasan sangat berpengaruh terhadap mutu susu bubuk selama penyimpanan. VM-PET12 sebenarnya masih dapat digunakan untuk mengemas susu bubuk karena memiliki bahan barrier tambahan dari PET. Metalized plastic dibuat melalu proses laminasi dengan beberapa kombinasi plastik dan logam alumunium. Penggunaan plastik ini sesuai untuk mengemas kopi, makanan kering, keju, roti panggang karena ketahanan uap air dan gas meningkat dan kemasan ini tidak meneruskan cahaya dan menghambat oksigenmasuk kedalam produk yang dikemas (Brown, 1992).

Meskipun demikian metalized plastic lebih rentan terhadap uap air jika dibandingkan dengan alumunium foil. Dibalik itu semua metalized plastic memiliki beberapa keunggulan dibandingkan alumunium foil diantaranya adalah harga yang relatif murah dibandingkan alumunium foil, lebih tahan terhadap goresan, dan tidak mudah crack / retak (Sampurno, 2006). Keunggulan tersebut dapat menekan biaya penggunaan kemasan, memperbaiki tampilan kemasan lebih premium, dan menjaga mutu produk dari benturan fisik benda lain, sehingga kemasan tidak mudah berlubang. Dengan demikian jika hasil perhitungan umur simpan dengan pengemas metalized plastic masih memenuhi target umur simpan produk, maka metalized plastic dapat digunakan sebagai pengemas untuk menghindari over spek kemasan.

\section{KESIMPULAN}

Umur simpan produk susu bubuk yang dikemas menggunakan alumunium foil $7 \mu$ (AL7) berdasarkan parameter kadar air yaitu 518.3 hari atau 17.2 bulan, sedangkan berdasarkan DCT (Difference from Control Test) yaitu 50.2 bulan atau 4.1 tahun. Umur simpan susu bubuk yang dikemas menggunakan metalized plastic $12 \mu$ (VM-PET12) berdasarkan kadar air yaitu 12.0 bulan atau 1.0 tahun, sedangkan 
berdasarkan DCT yaitu 33.8 bulan atau 2.8 tahun.

\section{DAFTAR PUSTAKA}

Brown, EW. 1992. Plastic in Food Packaging, Properties, Design, and Fabrication. Mercell Dekker Inc., NY.

Eskin, M dan D. Robinson. 2001. Food Shelf Life Stability:Chemical, Biochemical and Microbial Chages. CRC Press, Danvers USA.

Herawati, H. 2008. Pendugaan Umur Simpan pada Produk Pangan. Jurnal Litbang Pertanian 27(4) Hlm. 124 - 130. Balai Pengkajian Teknologi Pertanian Jawa Tengah. Ungaran, Jawa Tengah.

Hariyadi, P. 2012. Aplikasi Prinsip Kinetika untuk Penentuan Masa Simpan Produk Pangan.Makalah Pelatihan Institut Pertanian Bogor. Bogor.

Sampurno, R. 2006. Aplikasi Polimer Dalam Industri Kemasan. Jurnal Sains Materi Indonesia. Edisi Khusus Oktober 2006, hal : 15 - 22 ISSN : 1411-1098. Tangerang.

SNI 2970:2015. Tentang Susu Bubuk.Badan Standarisasi Nasional.

Syalfina, M. 2007. Pendugaan Umur Simpan Permen Jahe dengan Menggunakan Metode Accelerated Shelf Life Testing (ASLT) dengan Pendekatan Model Kadar Air Kritis.Skripsi Fakultas Teknologi Pertanian Institut Pertanian Bogor. Bogor.

Syarief, R., dkk. 1989. Teknologi Pengemasan Laboratorium Rekayasa Proses Pangan.PAU Pangan dan Gizi, Institut Pertanian Bogor. Bogor. 